\title{
Role of adenosine in the regulation of coronary blood flow in swine at rest and during treadmill exercise
}

\author{
DIRK J . DUNCKER, RENE STUBENITSKY, AND PIETER D. VERDOUW \\ Experimental Cardiology, Thoraxcenter, Cardiovascular Research Institute COEUR, \\ Erasmus University Rotterdam, 3000 DR Rotterdam, The Netherlands
}

\begin{abstract}
Duncker, Dirk J ., René Stubenitsky, and Pieter D. Verdouw. Role of adenosine in the regulation of coronary blood flow in swine at rest and during treadmill exercise. Am. J. Physiol. 275 (Heart Circ. Physiol. 44): H1663-H1672, 1998.-A pivotal role for adenosine in the regulation of coronary blood flow is still controversial. Consequently, we investigated its role in the regulation of coronary vasomotor tone in swine at rest and during graded treadmill exercise. During exercise, myocardial $\mathrm{O}_{2}$ consumption increased from $167 \pm 18 \mu \mathrm{mol} / \mathrm{min}$ at rest to $399 \pm 27 \mu \mathrm{mol} / \mathrm{min}$ at $5 \mathrm{~km} / \mathrm{h}$ $(\mathrm{P} \leq 0.05)$, which was paralleled by an increase in $\mathrm{O}_{2}$ delivery, so that myocardial $\mathrm{O}_{2}$ extraction ( $76 \pm 1$ and $78 \pm 1 \%$ at rest and $5 \mathrm{~km} / \mathrm{h}$, respectively) and coronary venous $\mathrm{PO}_{2}(24.5 \pm 1.0$ and $22.8 \pm 0.3 \mathrm{mmHg}$ at rest and $5 \mathrm{~km} / \mathrm{h}$, respectively) remained unchanged. After adenosine receptor blockade with 8-phenyltheophylline ( $5 \mathrm{mg} / \mathrm{kg}$ iv), the relation between myocardial $\mathrm{O}_{2}$ consumption and coronary vascular resistance was shifted toward higher resistance, whereas myocardial $\mathrm{O}_{2}$ extraction rose to $81 \pm 1$ and $83 \pm 1 \%$ at rest and $5 \mathrm{~km} / \mathrm{h}$ and coronary venous $\mathrm{PO}_{2}$ fell to $19.2 \pm 0.8$ and $18.9 \pm 0.8 \mathrm{mmHg}$ at rest and $5 \mathrm{~km} / \mathrm{h}$, respectively (all $\mathrm{P} \leq 0.05$ ). Thus, although adenosine is not mandatory for the exercise-induced coronary vasodilation, it exerts a vasodilator influence on the coronary resistance vessels in swine at rest and during exercise.
\end{abstract}

coronary circulation; myocardial oxygen extraction; myocardial oxygen consumption; pulmonary circulation; systemic circulation

THE NORMAL HEART IS characterized by a high myocardial $\mathrm{O}_{2}$ extraction $\left(\mathrm{MEO}_{2}\right)$, requiring a tight coupling of coronary blood flow to changing metabolic needs (16, 26). The close coupling of coronary blood flow and myocardial $\mathrm{O}_{2}$ demand has been proposed to depend primarily on messengers released from the myocardium, such as adenosine $(4,30)$. Although adenosine has been shown to contribute to coronary vasodilation in isolated rodent hearts, a pivotal role for adenosine in the regulation of coronary blood flow in the large mammalian in situ heart is still controversial. Thus neither increased adenosine catabolism with adenosine deaminase nor adenosine receptor blockade with the adenosine $A_{1} / A_{2}$-receptor blocker 8-phenyltheophylline (8-PT) altered resting coronary blood flow in anesthetized or awake dogs $(2,22,24,33)$. In addition, during treadmill exercise, coronary blood flow and resistance, as.well as myocardial $\mathrm{O}_{2}$ consumption $\left(\mathrm{MVO}_{2}\right)$ and $\mathrm{MEO}_{2}$, were not altered by adenosine receptor blockade or adenosine deaminase (2), suggesting that adenosine

The costs of publication of this article were defrayed in part by the payment of page charges. The article must therefore be hereby marked "advertisement" in accordance with 18 U.S.C. Section 1734 solely to indicate this fact. is not mandatory for the regulation of coronary blood flow in the dog heart at rest or during exercise. In contrast, several studies have reported that adenosine receptor blockade produced by theophyl]ine increased coronary vascular resistance and $\mathrm{MEO}_{2}$ and decreased coronary blood flow and coronary venous Po2 $\left(\mathrm{PCV}_{\mathrm{O}_{2}}\right)$ in the human heart under basal conditions (11-13), whereas only one study reported no change in resting coronary blood flow after adenosine receptor blockade with aminophylline (32). Also, in closed-chest sedated swine, adenosine deaminase produced a small increase in coronary vasomotor tone under basal conditions (17) while markedly blunting the early coronary blood flow response to intracoronary infusions of isoproterenol (18). Recently, we observed in swine that exercise produced increases in $\mathrm{MVO}_{2}$ that were matched by equivalent increments in coronary blood flow so that $\mathrm{MEO}_{2}$ and $\mathrm{PCV}_{\mathrm{O}_{2}}$ were maintained (9). Because interstitial adenosine levels have been reported to increase during $\beta$-adrenergic stimulation with dobutamine in anesthetized swine at a time when $\mathrm{PCV}_{\mathrm{O}_{2}}$ or interstitial lactate levels did not change (21), it is possible that adenosine could contribute to the maintained $\mathrm{PCV}_{\mathrm{O}_{2}}$ in swine during exercise. Consequently, in the present study we investigated the role of adenosine in the coupling between myocardial $\mathrm{O}_{2}$ delivery $\left(\mathrm{MDO}_{2}\right)$ and $\mathrm{MVO}_{2}$ in awake swine at rest and during graded treadmill exercise up to $85-90 \%$ of maximum heart rate (4a).

\section{MATERIALS AND METHODS}

Crossbred Landrace $\times$ Yorkshire pigs were used in the present study. All experiments were performed in accordance with the "Guiding Principles in the Care and U se of Laboratory Animals," as approved by the Council of the American Physiological Society and with prior approval of the Animal Care Committee of the E rasmus University Rotterdam. Adaptation of animals to the laboratory conditions started $1 \mathrm{wk}$ before the day of surgery and continued until 10 days postoperative. Full details of the experimental procedures have been published previously $(7,9,37,38)$.

\section{Surgical Procedures}

After an overnight fast, seven pigs ( $23 \pm 1 \mathrm{~kg} ; 3$ males and 4 females) were sedated with ketamine $(30 \mathrm{mg} / \mathrm{kg} \mathrm{im}$; K etalin, Apharmo, Arnhem, The Netherlands), anesthetized with thiopental sodium (10 mg/kg iv; Rhône-Poulenc, Amstelveen, The Netherlands), intubated, and mechanically ventilated with a mixture of $\mathrm{O}_{2}$ and nitrous oxide (1:2) to which $0.2-1.0 \%$ ( $\mathrm{vol} / \mathrm{vol}$ ) isoflurane (F orene, Abbott, Amstelveen, The Netherlands) was added. Anesthesia was further maintained with midazolam (2 $\mathrm{mg} / \mathrm{kg}+1 \mathrm{mg} \cdot \mathrm{kg}^{-1} \cdot \mathrm{h}^{-1} \mathrm{iv}$; Dormicum, Roche, Mijdrecht, The Netherlands) and fentanyl (10 $\mu \mathrm{g} \cdot \mathrm{kg}^{-1} \cdot \mathrm{h}^{-1} \mathrm{iv}$; $\mathrm{J}$ anssen-Cilag, Tilburg, The Netherlands). Under sterile conditions, the chest was opened via the fourth left intercostal 
space, and an 8-Fr fluid-filled polyvinylchloride (PVC) catheter was inserted into the aortic arch for the measurement of central aortic blood pressure and collection of arterial blood samples and secured with a purse-string suture. After the pericardium was opened, an electromagnetic flow probe (14$15 \mathrm{~mm}$ ID) was positioned around the ascending aorta for the measurement of ascending aortic blood flow (Transflow 601 Systems, Skalar, Delft, The Netherlands). A high-fidelity pressure transducer (model $\mathrm{P}_{4.5}$, Konigsberg Instruments, Pasadena, CA) was inserted into the left ventricle (LV) via the apical dimple for recording of LV pressure and its first derivative (LV dP/dt; obtained via electrical differentiation). An 8-Fr PVC catheter was also inserted into the LV for calibration of the Konigsberg transducer signal; two 8-Fr PVC catheters were inserted into the pulmonary artery for measurement of pulmonary arterial pressure, withdrawal of mixed venous blood samples, and administration of drugs. Another 8-Fr catheter was inserted into the left atrium for measurement of left atrial pressure. For the measurement of coronary blood flow, a Doppler flow probe $(2.0,2.5$, or $3.0 \mathrm{~mm}$ ID, emitting frequency $=20 \mathrm{MHz}$ ) was placed around the proximal part of the left anterior descending (LAD) coronary artery (model HVPD-20, Crystal Biotech, Northboro, MA) (23). A small angiocatheter $(0.8 \mathrm{~mm} \mathrm{ID}, 1.1 \mathrm{~mm} \mathrm{OD})$ connected to a larger Tygon catheter (0.8 mm ID, $2.4 \mathrm{~mm}$ OD) was inserted directly into the anterior interventricular vein to allow sampling of coronary venous blood (5). Electrical wires and catheters were tunneled subcutaneously to the back, the chest was closed, and the animals were allowed to recover. All el ectrical wires and catheters were protected with a vest.

Postsurgical period. After surgery the animals received analgesia by daily intramuscular injections of $0.3 \mathrm{mg}$ of buprenorphine (Temgesic, Schering-Plough, Amstelveen, The N etherlands) during the first $48 \mathrm{~h}$ and intravenous injections of $25 \mathrm{mg} / \mathrm{kg}$ of amoxicillin (Clamoxil, Beecham Farma, Amstelveen, The Netherlands) and $5 \mathrm{mg} / \mathrm{kg}$ gentamicin (A.U.V., Cuijk, The Netherlands) on a daily basis during the 1st wk to prevent infections. Catheters were flushed daily with physiological saline containing 2,000 IU/ml heparin (Leo Pharmaceutical Products, Weesp, The Netherlands).

\section{Experimental Protocols}

Exercise protocols. Studies were performed 10-20 days after surgery with animals exercising on a motor-driven treadmill. Two experimental protocols were performed on different days and in random order. The first protocol was performed to establish that two consecutive exercise tests performed at 90-min intervals produced reproducible results; in the second protocol the effect of nonselective adenosine $A_{1} / A_{2}$-receptor blockade was studied.

Reproducibility of responses to exercise With swine lying quietly on the treadmill, resting hemodynamic measurements, consisting of ascending aortic blood flow, LV pressure and LV dP/dt, blood pressures in the aorta, pulmonary artery, and left atrium, and the coronary Doppler shift, were obtained, and arterial, mixed venous, and coronary venous blood samples were collected $(9,38)$. Aortic, pulmonary, and left atrial pressures were measured using Combitrans pressure transducers (Braun, Melsungen, Germany) with the reference point at midchest level. In one of the seven animals, samples could not be obtained from the coronary venous catheter. All hemodynamic measurements were repeated, and rectal temperature was measured with animals standing on the treadmill. Subsequently, a five-stage treadmill exercise protocol was started $[1,2,3,4$, and $5 \mathrm{~km} / \mathrm{h}$ resulting in $85-90 \%$ of maximum heart rate (4a)]; each exercise stage lasted 2-3 min. Hemodynamic variables were continuously recorded, and blood samples were collected during the last $45 \mathrm{~s}$ of each exercise stage, at a time when hemodynamics had reached a steady state. After completing the exercise protocol, animals were allowed to rest on the treadmill for $90 \mathrm{~min}$, and then resting measurements were obtained and the five-stage exercise protocol was repeated.

Adenosine receptor blockade Ninety minutes after swine had undergone a control exercise period, animals received an infusion of 8-PT ( $5 \mathrm{mg} / \mathrm{kg}$ administered over $5 \mathrm{~min}$ into a pulmonary artery catheter) to produce adenosine receptor blockade (20). It has previously been shown that this dose of 8-PT produces $>95 \%$ inhibition of adenosine-induced coronary vasodilation in anesthetized swine (8) and awake dogs $(2,10)$. Five minutes after completion of the 8-PT infusion, resting measurements were obtained and the exercise protocol was repeated.

Contribution of changes in $\mathrm{pH}$ and $\mathrm{PCO}_{2}$ to the 8-PT-induced alterations in $\mathrm{MEO}_{2}$. Because we observed that 8-PT decreased arterial and coronary venous $\mathrm{PCO}_{2}$ and increased arterial $\mathrm{pH}$, which could potentially increase coronary vasomotor tone, we determined the effects of equival ent hyperventilation-induced decreases in arterial and coronary venous $\mathrm{PCO}_{2}$ and increases in $\mathrm{pH}$ on $\mathrm{MEO}_{2}$ and $\mathrm{PCv}_{\mathrm{O}_{2}}$ in five swine (2 chronically instrumented ketamine-sedated swine and three pentobarbital-anesthetized intubated open-chest animals) (15). After $5 \mathrm{~min}$ of hyperventilation, arterial and coronary venous samples were obtained. In addition, we obtained arterial and coronary venous blood samples before and $5 \mathrm{~min}$ after infusion of $1 \mathrm{M}$ sodium hydrogen bicarbonate ( $L$ ansberg, Uden, The Netherlands), which produced similar increases in $\mathrm{pH}$ in the two chronically instrumented ketamine-sedated swine.

\section{Blood Gas Measurements}

Blood samples were maintained in iced syringes until the conclusion of each exercise trial. $\mathrm{PO}_{2}(\mathrm{mmHg}), \mathrm{PCO}_{2}(\mathrm{mmHg})$, and $\mathrm{pH}$ were then immediately measured with a blood gas analyzer (Acid-Base Laboratory model 505, Radiometer, Copenhagen, Denmark). $\mathrm{O}_{2}$ saturation $\left(\mathrm{SO}_{2}\right)$ and $\mathrm{Hb}(\mathrm{g} / 100 \mathrm{ml})$ were measured with a hemoximeter (model OSM2, Radiometer, Copenhagen, Denmark).

\section{Data Acquisition and Analysis}

All hemodynamic data were recorded and digitized (400 $\mathrm{Hz}$ /channel) on-line using an eight-channel data-acquisition program (ATCODAS, Dataq Instruments, Akron, OH) and stored on a computer for later postacquisition off-lineanalysis with a program written in MatLab (Mathworks, Natick, MA). A minimum of 15 consecutive beats were selected for analysis of the digitized hemodynamic signals. From these selected beats the LV peak systolic pressure, mean aortic blood pressure, mean pulmonary arterial and mean left atrial pressure, mean ascending aortic blood flow, and mean coronary Doppler shift were determined for each beat and averaged.

Cardiac output was computed as the sum of ascending aortic blood flow (measured with the electromagnetic flow probe) and total coronary blood flow. Because the LAD coronary artery supplies $\sim 40 \%$ of the LV, total coronary blood flow was taken as 2.5 times flow in the LAD coronary artery. Systemic and coronary vascular resistance were calculated as the ratios of mean aortic pressure to cardiac output and mean aortic pressure to LAD coronary blood flow, respectively. Blood $\mathrm{O}_{2}$ content $(\mu \mathrm{mol} / \mathrm{ml})$ was computed as $\left(0.621 \cdot \mathrm{Hb}_{\mathrm{a}} \cdot \mathrm{So}_{2}\right)+$ $\left(0.00131 \cdot \mathrm{PO}_{2}\right)$, where $\mathrm{Hb}_{\mathrm{a}}$ is arterial $\mathrm{Hb}$. $\mathrm{MDO}_{2}$ was computed as the product of arterial $\mathrm{O}_{2}$ content and LAD coronary blood flow; whole body $\mathrm{O}_{2}$ delivery was calculated as the product of arterial $\mathrm{O}_{2}$ content and cardiac output. $\mathrm{MVO}_{2}$ in the region 
perfused by the LAD coronary artery was calculated as the product of coronary blood flow and the difference in $\mathrm{O}_{2}$ content between arterial. and coronary venous blood; whole body $\mathrm{O}_{2}$ consumption $\left(\mathrm{BVO}_{2}\right)$ was calculated as the product of cardiac output and difference in $\mathrm{O}_{2}$ content between arterial and mixed venous blood. $\mathrm{MEO}_{2}$ was computed as the ratio of arterial-coronary venous $\mathrm{O}_{2}$ content difference to arterial $\mathrm{O}_{2}$ content; whole body $\mathrm{O}_{2}$ extraction $\left(\mathrm{BEO}_{2}\right)$ was calculated as the ratio of arterial-mixed venous $\mathrm{O}_{2}$ content difference to arterial $\mathrm{O}_{2}$ content.

Statistical analysis of the exercise data was performed using two-way (exercise and treatment) ANOVA for repeated measures. When a significant effect of exercise was observed, post hoc testing was done using Dunnett's test. When a significant effect of treatment was observed, post hoc testing was done using paired t-test or Wilcoxon signed rank test as appropriate. The effect of hyperventilation was tested using paired t-test or Wilcoxon signed rank test. $P \leq 0.05$ was considered statistically significant (2-tailed). Values are means \pm SE

\section{Drugs}

8-PT (Sigma-Aldrich, Bornem, Belgium) was dissolved in $20 \mathrm{ml}$ of demineralized water at $30^{\circ} \mathrm{C}(\mathrm{pH} \mathrm{10-11).} \mathrm{Fresh} \mathrm{drug}$ solutions were prepared on each day.

\section{RESULTS}

\section{Reproducibility of Responses to Exercise}

Exercise increased cardiac output from $3.5 \pm 0.2$ $\mathrm{I} / \mathrm{min}$ at rest (supine) to $7.9 \pm 0.5 \mathrm{l} / \mathrm{min}$ at $5 \mathrm{~km} / \mathrm{h}(\mathrm{P} \leq$
$0.01)$, which was principally due to an increase in heart rate from $110 \pm 4$ to $242 \pm 4$ beats $/ \mathrm{min}(P \leq 0.01)$ as stroke volume increased $\sim 10 \%$ (Table 1 ). Because afterload increased (reflected by the increase in LV systolic pressure from $120 \pm 4 \mathrm{mmH}$ g at rest to $145 \pm 5$ $\mathrm{mmHg}$ at $5 \mathrm{~km} / \mathrm{h}, \mathrm{P} \leq 0.01$ ), the increase in stroke volume was likely the result of an increase in LV filling pressure (reflected by the increase in left atrial pressure from $6 \pm 1$ to $14 \pm 2 \mathrm{mmHg}, \mathrm{P} \leq 0.01)$ and an increase in LV contractility (reflected by the increase in $\mathrm{LV} \mathrm{dP/dt}$ max from 3,080 \pm 290 to $6,220 \pm 380 \mathrm{mmH} \mathrm{g} / \mathrm{s}$, $P \leq 0.01$ ). Mean aortic pressure decreased slightly when the animals went from a supine to an upright position, but during exercise, aortic pressure increased from $92 \pm 4 \mathrm{mmHg}$ while animals were standing to $97 \pm 4 \mathrm{mmHg}$ at $5 \mathrm{~km} / \mathrm{h}(\mathrm{P} \leq 0.05)$. The $5 \%$ increase in mean aortic blood pressure in the presence of a doubling of cardiac output implies that systemic vascular resistance had decreased. In contrast, mean pulmonary arterial pressure increased from $14 \pm 1$ to $33 \pm 2$ $\mathrm{mmHg}(\mathrm{P} \leq 0.01)$, and the driving pressure across the pulmonary vascular bed increased virtually in parallel with cardiac output, so that pulmonary vascular resistance was not significantly altered. Blood flow through the LAD coronary artery increased from $45 \pm 4 \mathrm{ml} / \mathrm{min}$ at rest to $95 \pm 11 \mathrm{ml} / \mathrm{min}$ during the highest level of exercise ( $\mathrm{P} \leq 0.01$; Table 1 ). After $90 \mathrm{~min}$ of rest, at a time when all hemodynamic variables had returned to baseline resting values, the second period of exercise

Table 1. Reproduci bility of hemodynamic responses in swine during consecutive periods of graded treadmill exercise

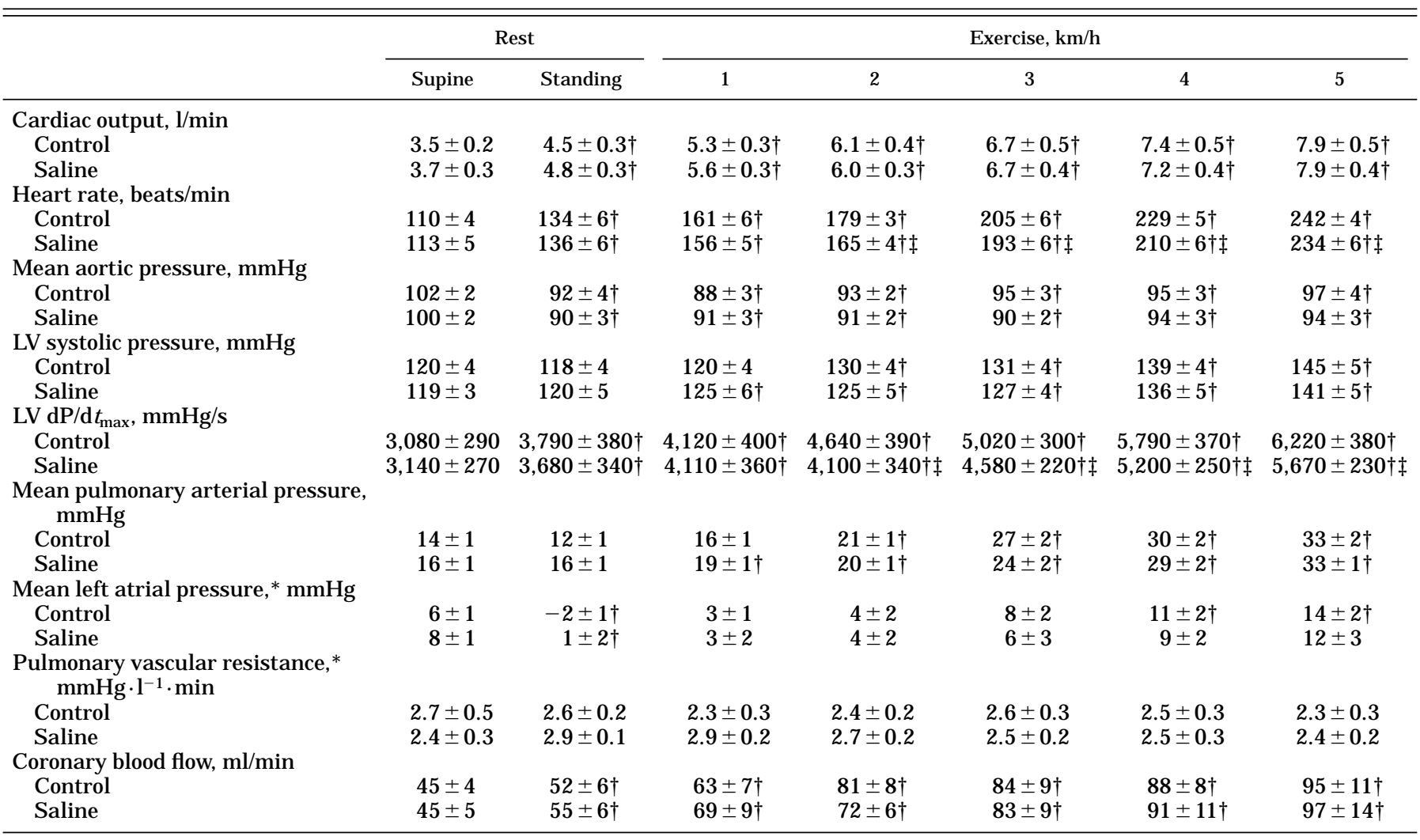

Values are means $\pm S E ; n=7$ unless otherwise noted. LV, left ventricle; $d P / d t_{\text {max }}$, maximum rate of rise in pressure. * $n=4$. $\dagger P \leq 0.05$ vs. supine; $¥ P \leq 0.05$ vs. corresponding control. 
Table 2. Reproducibility of blood gas and $\mathrm{O}_{2}$ transport responses in swineduring consecutive periods of graded treadmill exercise

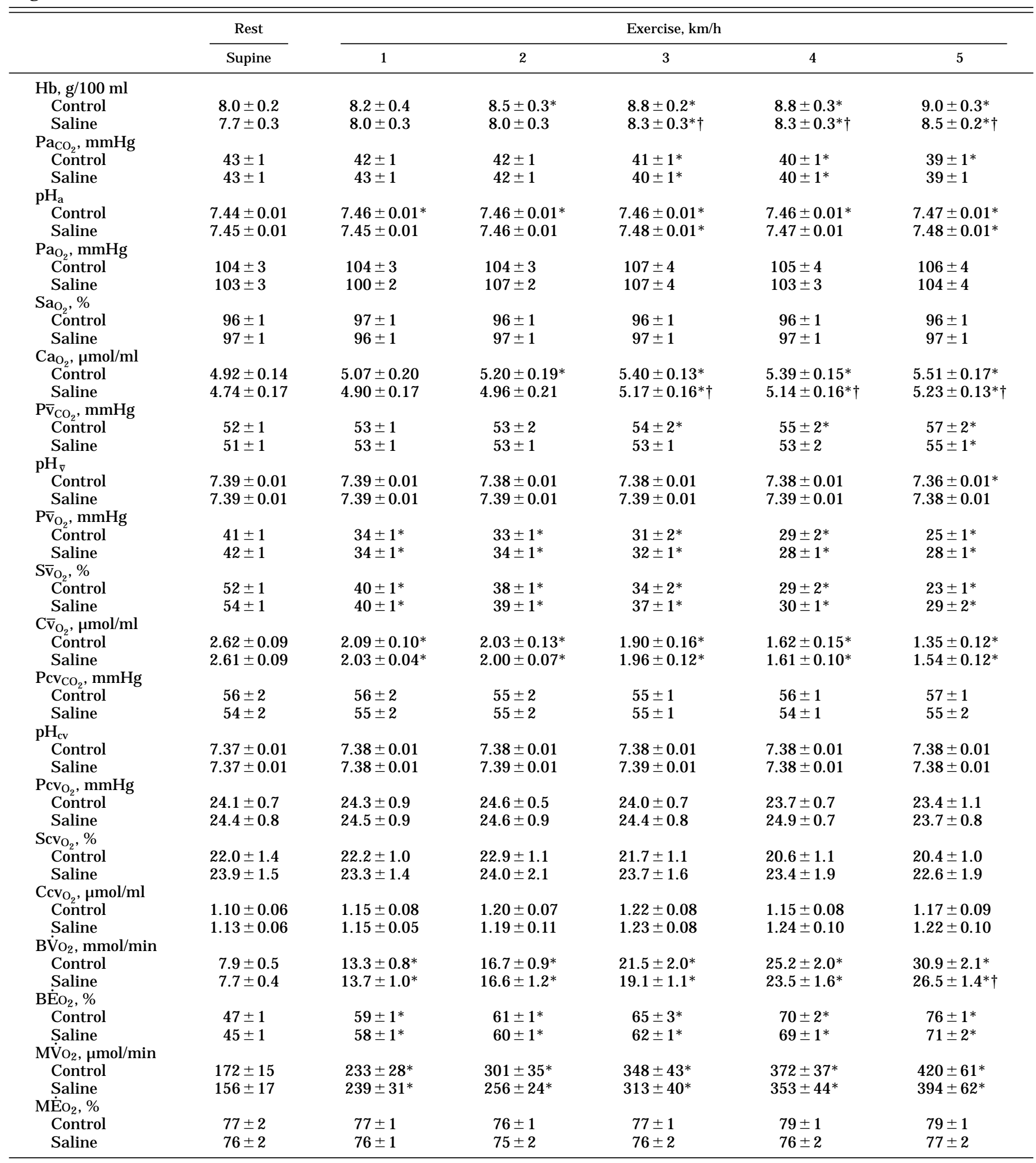

Values are means $\pm \mathrm{SE} ; \mathrm{n}=7$. $\mathrm{Pa}_{\mathrm{CO}_{2}}, \mathrm{pH}_{\mathrm{a}}, \mathrm{Pa}_{\mathrm{O}_{2}}, \mathrm{Sa}_{\mathrm{O}_{2}}$, and $\mathrm{Ca}_{\mathrm{O}_{2}}$, arterial $\mathrm{PCO}_{2}, \mathrm{pH}, \mathrm{Po}_{2}, \mathrm{O}_{2}$ saturation, and $\mathrm{O}_{2}$ content; $\mathrm{P}_{\mathrm{CO}_{2}}$, $\mathrm{pH}_{\overline{\mathrm{v}}}$, $\mathrm{P}_{\mathrm{O}_{2}}, \mathrm{~Sv}_{\mathrm{O}_{2}}$, and $\mathrm{CV}_{\mathrm{O}_{2}}$, mixed venous $\mathrm{PCO}_{2}, \mathrm{pH}, \mathrm{PO}_{2}, \mathrm{O}_{2}$ saturation, and $\mathrm{O}_{2}$ content; $\mathrm{PCv}_{\mathrm{CO}_{2}}, \mathrm{pH}_{\mathrm{Cv}}, \mathrm{PCV}_{\mathrm{O}_{2}}, \mathrm{Scv}_{\mathrm{O}_{2}}$, and $\mathrm{CCv}_{\mathrm{O}_{2}}$, coronary venous $\mathrm{PCO}_{2}, \mathrm{pH}, \mathrm{PO}_{2}, \mathrm{O}_{2}$ saturation, and $\mathrm{O}_{2}$ content; $\mathrm{BVO}_{2}$ and $\mathrm{BE}_{2}$, whole body $\mathrm{O}_{2}$ consumption and extraction; $\mathrm{MVO}_{2}$ and $\mathrm{MEO}_{2}$, myocardial $\mathrm{O}_{2}$ consumption and extraction. $* \mathrm{P} \leq 0.05$ vs. supine; $† \mathrm{P} \leq 0.05$ vs. corresponding control. 
resulted in almost identical hemodynamic responses to exercise, with the exception of heart rate and LV $\mathrm{dP} / \mathrm{dt}_{\max }$, which were slightly $(<10 \%)$ lower during exercise at $2-5 \mathrm{~km} / \mathrm{h}$ than during the first run (Table 1 ).

Exercise resulted in a decrease in arterial $\mathrm{PCO}_{2}$ from $43 \pm 1 \mathrm{mmHg}$ at rest to $39 \pm 1 \mathrm{mmHg}$ at $5 \mathrm{~km} / \mathrm{h}$ and an increase in arterial pH from $7.44 \pm 0.01$ to $7.47 \pm 0.01$ (both $\mathrm{P} \leq 0.05$; Table 2). Arterial $\mathrm{SO}_{2}$ did not change, but $\mathrm{Hb}$ and, hence, $\mathrm{O}_{2}$ content increased by $12 \%$ at the highest level of exercise compared with resting conditions. Mixed venous $\mathrm{PO}_{2}, \mathrm{SO}_{2}$, and $\mathrm{O}_{2}$ content decreased during exercise, whereas mixed venous $\mathrm{PCO}_{2}$ increased and $\mathrm{pH}$ decreased slightly. Because cardiac output and the arteriovenous $\mathrm{O}_{2}$ content difference nearly doubled, $\mathrm{BVO}_{2}$ increased fourfold from $7.9 \pm 0.5$ to $30.9 \pm 2.1$ $\mathrm{mmol} / \mathrm{min}(\mathrm{P} \leq 0.01$; Table 2, Fig. 1). All variables returned to baseline resting values within $90 \mathrm{~min}$; a second period of exercise resulted in nearly identical responses, with the exception of a slightly lower $\mathrm{Hb}$ and arterial $\mathrm{O}_{2}$ content at 3-5 km/h and a slightly lower $\mathrm{BVO}_{2}$ at $5 \mathrm{~km} / \mathrm{h}$ (Table 2, Fig. 1).

Exercise had no effect on coronary venous $\mathrm{PCO}_{2}, \mathrm{pH}$, $\mathrm{PO}_{2}, \mathrm{SO}_{2}$, or $\mathrm{O}_{2}$ content (Table 2, Fig. 2). $\mathrm{MVO}_{2}$ increassed from $172 \pm 15$ to $420 \pm 61 \mu \mathrm{mol} / \mathrm{min}$, whereas $\mathrm{MDo}_{2}$ increased from $214 \pm 25$ to $535 \pm 81 \mu \mathrm{mol} / \mathrm{min}$.(both $\mathrm{P} \leq 0.01$ ). Consequently, $\mathrm{MEO}_{2}$ (i.e., the ratio of $\mathrm{MVO}_{2}$ to $\mathrm{MDO}_{2}$ ) was not altered during exercise. All variables returned to baseline resting values within $90 \mathrm{~min}$. Despite the slightly lower heart rate, $\mathrm{LV} \mathrm{dP/dt}$ max , and arterial $\mathrm{O}_{2}$ content during the second control run, there were no differences between the two control runs with respect to coronary vascular resistance, $\mathrm{M} \dot{\mathrm{E}} \mathrm{O}_{2}, \mathrm{MDO}_{2}$, and $\mathrm{PCV}_{\mathrm{O}_{2}}$ when plotted as a function of $\mathrm{MVO}_{2}$ (Fig. 2).

\section{Adenosine Receptor Blockade}

Except for a $10 \%$ increase in heart rate, 8-PT had no effects on systemic and pulmonary hemodynamics at rest (Table 3). During exercise, heart rate at $5 \mathrm{~km} / \mathrm{h}$ and coronary blood flow at $1 \mathrm{~km} / \mathrm{h}$ were slightly higher than during control conditions.

8-PT decreased $\mathrm{PCO}_{2}$ and increased $\mathrm{pH}$ in arterial, mixed venous, and coronary venous blood (Table 4). Arterial $\mathrm{PO}_{2}, \mathrm{SO}_{2}$, and $\mathrm{O}_{2}$ content were maintained, but mixed venous $\mathrm{PO}_{2}, \mathrm{SO}_{2}$, and $\mathrm{O}_{2}$ content were lower in the presence of adenosine receptor blockade, reflecting an increase in $\mathrm{BEO}_{2}$ (Table 4, Fig. 1). The latter could only in part be explained by the increments in $\mathrm{BV}_{\mathrm{O}} \mathrm{O}_{2}$, inasmuch as the relation between $\mathrm{BVO}_{2}$ and $\mathrm{BEO}_{2}$ shifted upward toward higher $\mathrm{BEO}_{2}$ (not shown). The relation between $\mathrm{BVO}_{2}$ and systemic vascular resistance was also shifted upward toward higher resistance values (Fig. 1), suggesting that adenosine receptor blockade produced systemic vasoconstriction, which limited systemic $\mathrm{O}_{2}$ delivery, thereby resulting in an increase in $\mathrm{BEO}_{2}$ and, hence, a decrease in mixed venous $\mathrm{PO}_{2}$.

Administration of 8-PT resulted in increases in $\mathrm{MV}_{\mathrm{O}_{2}}$ that reached levels of statistical significance during exercise at 1 and $3 \mathrm{~km} / \mathrm{h}$. Thus the increase in coronary blood flow and $\mathrm{MDO}_{2}$ at $1 \mathrm{~km} / \mathrm{h}$ was likely due to an increase in $\mathrm{O}_{2}$ requirements. I mportantly, after admin-
A
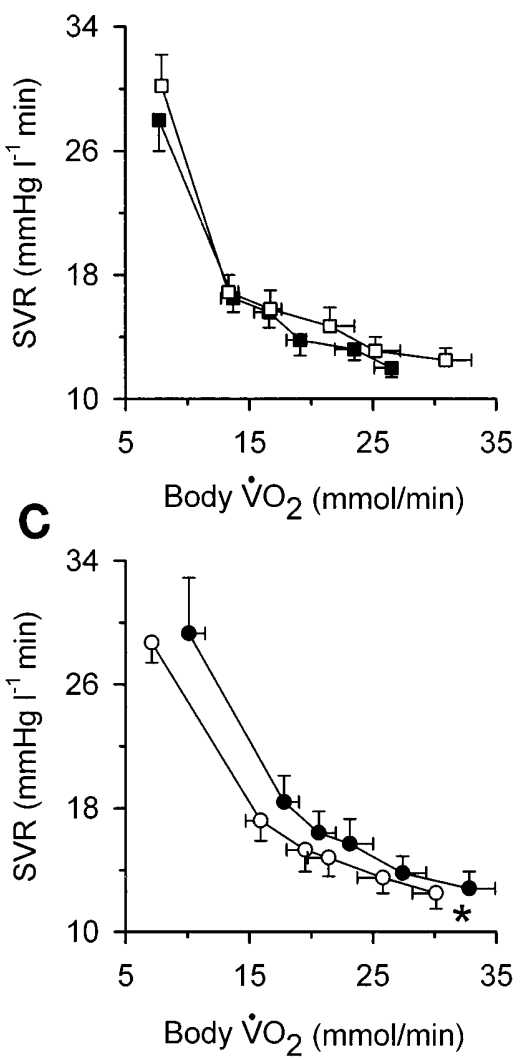

B
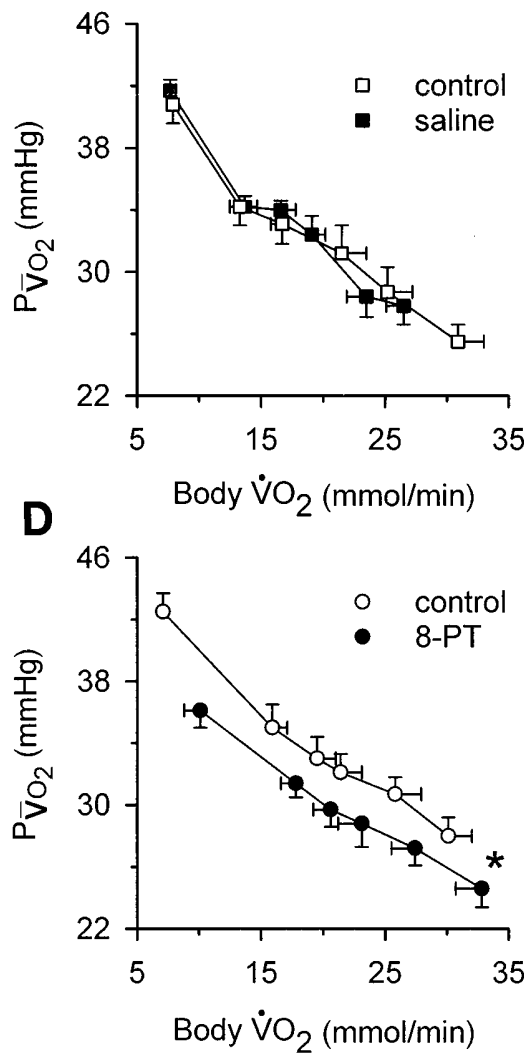

Fig. 1. Effects of saline (A and $B$ ) and adenosine receptor blockade produced by 8-phenyltheophylline (8-PT, $5 \mathrm{mg} / \mathrm{kg}$ iv; C and D) on relations between whole body $\mathrm{O}_{2}$ consumption (body $\mathrm{VO}_{2}$ ) and systemic vascular resistance (SVR) and between whole body $\mathrm{VO}_{2}$ and mixed venous $\mathrm{PO}_{2}$. Values (means $\pm \mathrm{SE}$ ) were obtained at rest (supine) and during 5 levels of treadmill exercise. $* \mathrm{P} \leq 0.05$ vs. control. 

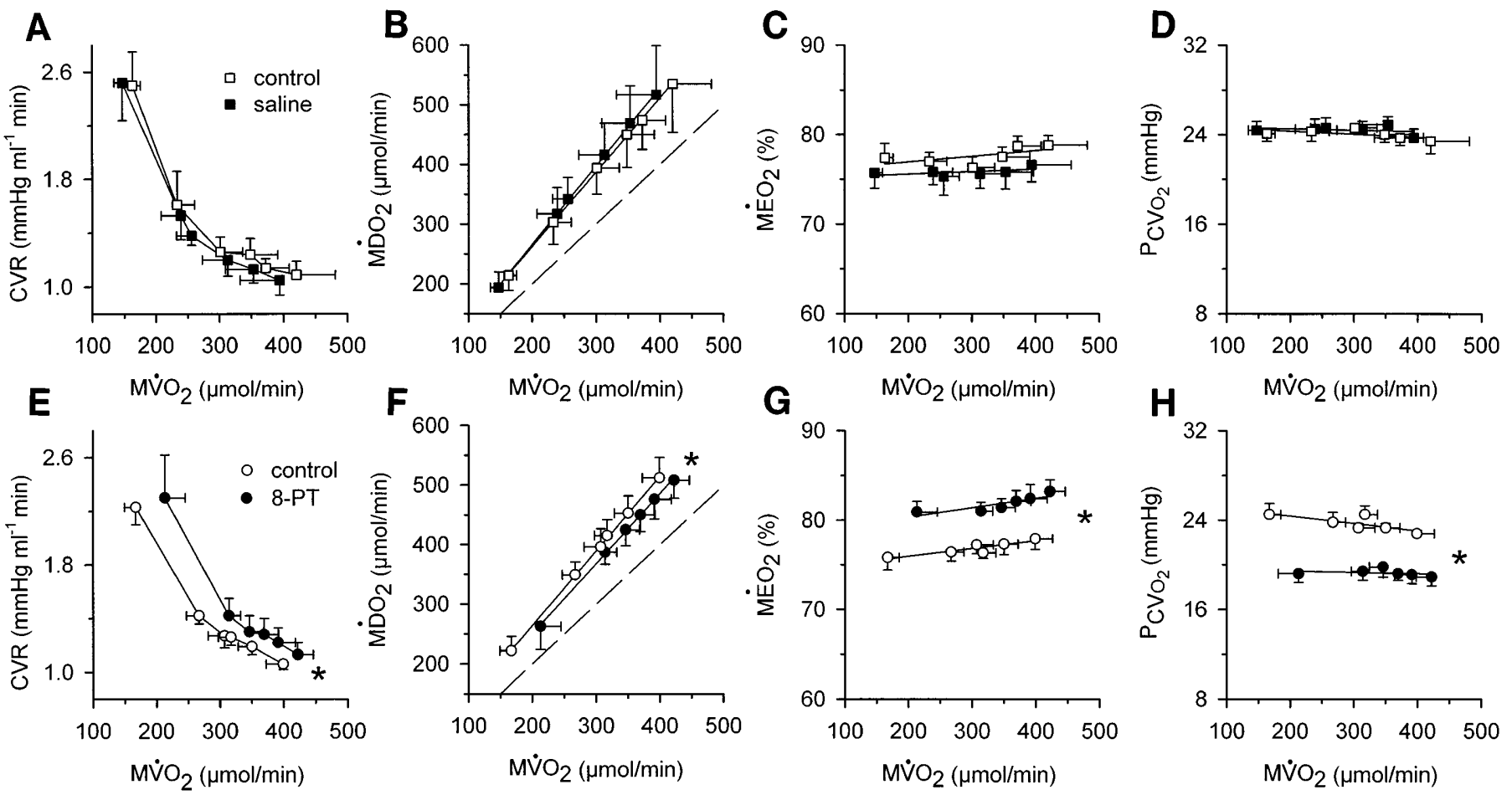

Fig. 2. Effects of saline (A-D) and adenosinne receptor blockade produced by 8-PT ( $5 \mathrm{mg} / \mathrm{kg}$ iv; $\mathrm{E}-\mathrm{H})$ on relations between myocardial $\mathrm{O}_{2}$ consumption $\left(\mathrm{MVO}_{2}\right.$ ) and coronary vascular resistance (CVR), myocardial $\mathrm{O}_{2}$ delivery $\left(\mathrm{MDO}_{2}\right)$, myocardial $\mathrm{O}_{2}$ extraction $\left(\mathrm{MEO}_{2}\right)$, and coronary venous $\mathrm{PO}_{2}\left(\mathrm{PcV}_{\mathrm{O}_{2}}\right)$. Values (means $\left.\pm \mathrm{SE}\right)$ were obtained at rest (supine) and during 5 levels of treadmill exercise. $* \mathrm{P} \leq 0.05 \mathrm{vs}$. control.

Table 3. Hemodynamic effects of adenosine receptor blockade in swineduring graded treadmill exercise

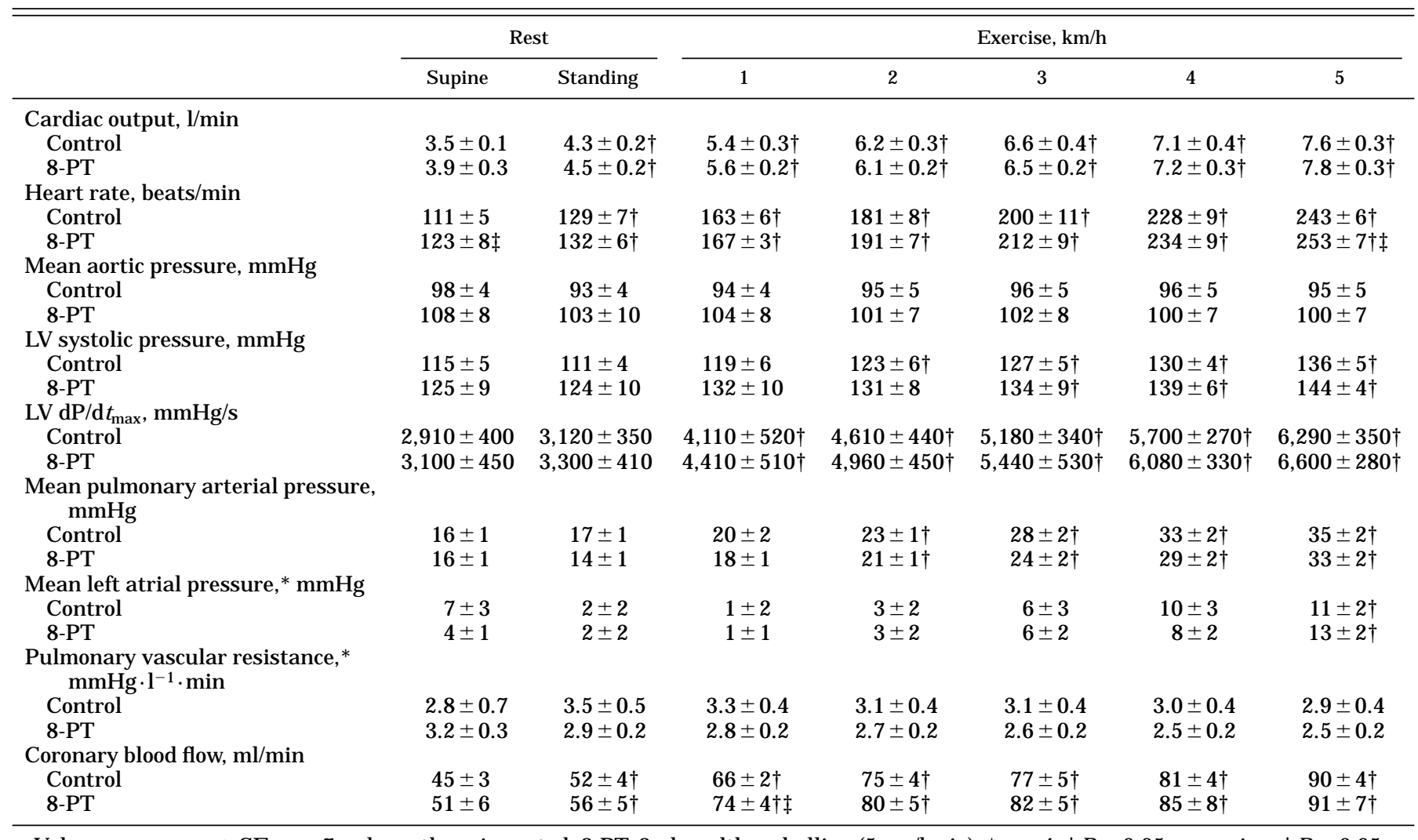

Values are means $\pm S E ; n=7$ unless otherwise noted. 8-PT, 8-phenyltheophylline $(5 \mathrm{mg} / \mathrm{kg}$ iv). $* n=4$. $† P \leq 0.05$ vs. supine; $\ddagger P \leq 0.05$ vs. corresponding control. 
Table 4. Effects of adenosine receptor blockade on $\mathrm{O}_{2}$ balance in swine during graded treadmill exercise

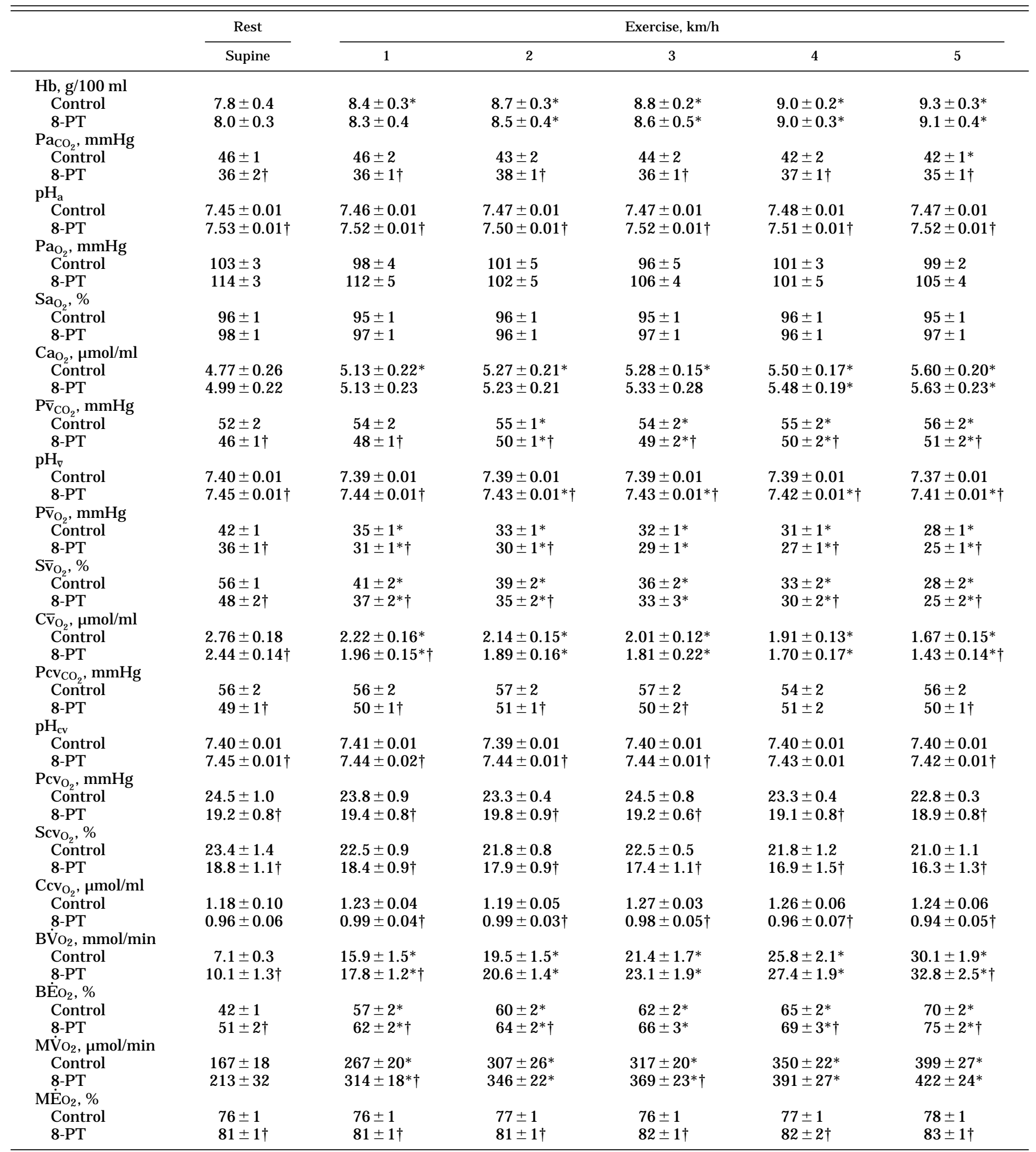

Values are means $\pm S E ; n=7$. $* P \leq 0.05$ vs. supine; $\uparrow P<0.05$ vs. corresponding control.

istratjon of 8-PT, $\mathrm{MD}_{2}$ was slightly lower at each level of $\mathrm{MVO}_{2}$ than under control conditions $(\mathrm{P} \leq 0.05)$ so that $\mathrm{MEO}_{2}$ increased and $\mathrm{PCV}_{\mathrm{O}_{2}}$ decreased (Table 4, Fig. 2), indicating an increase in vasomotor tone in the coronary resistance vessels that restricted $\mathrm{MDD}_{2}$. In support of this finding, the relation between $\mathrm{MVO}_{2}$ and coronary vascular resistance was shifted toward higher vascular resistance values (Fig. 2). 
Table 5, Effects of hyperventilation on blood gases and $\mathrm{MEO}_{2}$

\begin{tabular}{lcc}
\hline \hline & Baseline & Hyperventilation \\
\hline $\mathrm{Pa}_{\mathrm{CO}_{2}}, \mathrm{mmHg}$ & $47 \pm 5$ & $38 \pm 5^{*}$ \\
$\mathrm{pH}_{\mathrm{a}}$ & $7.44 \pm 0.03$ & $7.51 \pm 0.04^{*}$ \\
$\mathrm{PaO}_{2}, \mathrm{mmHg}$ & $95 \pm 5$ & $109 \pm 4^{*}$ \\
$\mathrm{PCV}_{\mathrm{CO}_{2}}, \mathrm{mmHg}$ & $56 \pm 5$ & $47 \pm 6^{*}$ \\
$\mathrm{pH}_{\mathrm{cv}}$ & $7.38 \pm 0.03$ & $7.44 \pm 0.04^{*}$ \\
$\mathrm{PCV}_{2}, \mathrm{mmHg}$ & $22.3 \pm 0.7$ & $22.4 \pm 1.7$ \\
$\mathrm{MEO}_{2}, \%$ & $77 \pm 2$ & $75 \pm 2$ \\
\hline
\end{tabular}

Values are means $\pm S E ; n=5 . * P \leq 0.05$ vs. baseline.

Contribution of Changes in $\mathrm{pH}$ and $\mathrm{PCO}_{2}$ to 8-PT-Induced Alterations in $\mathrm{MEO}_{2}$

Mechanical hyperventilation decreased arterial $\mathrm{PCO}_{2}$ from $47 \pm 5$ to $38 \pm 5 \mathrm{mmHg}$ and increased $\mathrm{pH}$ from $7.44 \pm 0.03$ to $7.51 \pm 0.04$ (all $P \leq 0.05$ ); similar changes were observed in the coronary venous blood. However, no changes were observed in $\mathrm{PCv}_{\mathrm{O}_{2}}$ or $\mathrm{MEO}_{2}$ (Table 5). Similarly, an increase in arterial $\mathrm{pH}$ from $7.39 \pm 0.03$ to $7.50 \pm 0.04$ produced by infusion of $1 \mathrm{M}$ $\mathrm{HCO}_{3}^{-}$in two sedated swine had no effect on $\mathrm{PCV}_{\mathrm{O}_{2}}$ $(23.6 \pm 0.6$ and $23.3 \pm 1.8 \mathrm{mmHg}$ before and after $\mathrm{HCO}_{3}^{-}$administration, respectively) or on $\mathrm{MEO}_{2}(77 \pm 3$ and $77 \pm 4 \%$, respectively). These findings indicate that 8-PT-induced changes in $\mathrm{PCO}_{2}$ and $\mathrm{pH}$ were not responsible for its vasoconstrictor actions.

\section{DISCUSSION}

The present study describes the contribution of adenosine in maintaining the balance between $\mathrm{MVO}_{2}$ and $\mathrm{MDO}_{2}$ in awake swine at rest and during treadmill exercise. The major findings of the present study were as follows:1) $\mathrm{MEO}_{2}$ and $\mathrm{PCv}_{\mathrm{O}_{2}}$ were not altered from resting levels during treadmill exercise at up to $80-90 \%$ of maximum heart rate (4a), indicating that the exercise-induced increases in $\mathrm{MVO}_{2}$ were matched by equivalent increases. in $\mathrm{MDO}_{2}$. 2) Adenosine receptor blockade increased $\mathrm{MEO}_{2}$ and decreased $\mathrm{PCv}_{\mathrm{O}_{2}}$ under resting conditions as well as during exercise, indicating that endogenously rel eased adenosine exerted a vasodilator influence that contributed to maintaining $\mathrm{MDO}_{2}$ commensurate with $\mathrm{O}_{2}$ demands. 3) Adenosine was not mandatory for the exercise-induced coronary vasodilation. 4) Changes in arterial or coronary venous $\mathrm{PCO}_{2}$ or $\mathrm{pH}$ could not account for these findings.

Adenosine has been proposed as one of the messengers that couples myocardial $\mathrm{O}_{2}$ demand to vasomotor tone of the coronary resistance vessels $(4,30)$. Adenine nucleotides do not cross the cell membrane of cardiac myocytes, but adenosine formed from the action of nucleotide phosphorylase on AMP can be transported out of myocytes into the interstitial space (36). On entering the interstitial space, adenosine can interact with $\mathrm{A}_{2}$ receptors on coronary vascular smooth muscle to produce vasodilation and an increase in coronary blood flow (30). Previous studies in dogs have demonstrated that endogenous adenosine production is not mandatory for maintaining resting coronary blood flow.
Thus studies in anesthetized open-chest dogs have generally failed to demonstrate an effect of intracoronary adenosine deaminase $(22,24,33)$ or intravenous aminophylline to block adenosine receptors $(19,34)$ on basal coronary blood flow, although some studies have reported an increase in coronary vascular resistance after administration of the sel ective adenosine receptor antagonist sulfophenyltheophylline (27). Similarly, in doses that caused marked inhibition of exogenous adenosine-induced coronary vasodilation, intracoronary adenosine deaminase or intravenous 8-PT had no effect on resting coronary blood flow, $\mathrm{MEO}_{2}$, or $\mathrm{Pcv}_{\mathrm{O}_{2}}$ in awake dogs (2).

In the in vivo canine heart, adenosine release is enhanced during conditions of increased myocardial $\mathrm{O}_{2}$ demand $(1,14,28,39)$. However, demonstration of an essential role for adenosine in mediating exerciseinduced coronary vasodilation requires that interruption of the adenosine effect interferes with exerciseinduced coronary vasodilation. Bache et al. (2) examined the effects of adenosine receptor blockade with 8-PT as well as augmented adenosine catabolism produced by intracoronary adenosine deaminase in exercising dogs. Adenosine antagonism inhibited coronary vasodilation evoked by ischemia; adenosine deaminase caused a 33-39\% decrease in reactive hyperemia after 5- to 20-s coronary occlusions, whereas 8-PT caused a 40-62\% decrease in reactive hyperemia. Neither agent significantly changed heart rate or arterial pressure during treadmill exercise. Furthermore, neither the absolute values for $\mathrm{MVO}_{2}$, coronary blood flow, and $\mathrm{Pc}_{\mathrm{O}_{2}}$ nor the relationship between these variables was altered by adenosine receptor blockade or adenosine deaminase (2). These findings indicate that adenosine is not obligatory for the increase in coronary blood flow produced by exercise in the dog heart.

In contrast to the results obtained in the dog heart, there is ample evidence that adenosine contributes to regulation of coronary vasomotor tone in the human heart. Edlund et al. (11-13) examined the effect of adenosine receptor blockade with theophylline on coronary sinus blood flow measured at rest and during supine bicycle exercise in normal young adult human subjects. Theophylline (3-6 mg/kg iv) caused a small increase in heart rate (13) and the rate-pressure product (12), but, despite increased myocardial $\mathrm{O}_{2}$ demands, coronary blood flow and coronary venous $\mathrm{SO}_{2}$ were lower, whereas coronary vascular resistance and $\mathrm{MEO}_{2}$ were higher, after theophylline at rest and during exercise (11-13). The results of the present study obtained in awake swine support the findings by Edlund and co-workers and suggest that endogenous adenosine exerts a vasodilator influence on the coronary circulation at rest and during exercise but is not mandatory for the increase in coronary blood flow and decrease in coronary vascular resistance produced by exercise in swine and humans. These findings could be interpreted to suggest that adenosine contributes to a basal offset point of coronary vasomotor tone but that adenosine does not contribute to the decreasein vasomotor tone produced by exercise. However, in closed-chest 
sedated swine, increased adenosine catabolism with intracoronary administration of adenosine deaminase, which had no effect on the steady-state coronary blood flow responseto isoproterenol (after 10 min of infusion), markedly blunted the early (at 1 min) coronary blood flow response to intracoronary infusions of isoproterenol (18). In the present study we obtained measurements after 2-3 min of exercise, so we cannot exclude the possibility that adenosine may have contributed to the early adaptation of vasomotor tone ( $\leq 1 \mathrm{~min}$ ) during treadmill exercise. In addition, it is possible that adenosine also contributes to coronary vasodilation during steady-state exercise but that other vasodilator mechanisms, e.g., NO or ATP-sensitive $\mathrm{K}^{+}$channel activation, act to compensate and mediate the vasodilation when adenosine receptors are blocked (26). Future studies, employing a combination of blockers of these different vasodilator systems, are needed to determine whether adenosine contributes to the coronary vasodilation produced by exercise in swine. However, the present study clearly demonstrates that adenosine is not mandatory for steady-state exercise-induced vasodilation in swine.

In dogs the exercise-induced increase in coronary blood flow does not fully match the increase in myocardial $\mathrm{O}_{2}$ demand, so even during mild-to-moderate exercise $\left(<70 \%\right.$ of maximum heart rate) $\mathrm{MEO}_{2}$ increases and, hence, $\mathrm{PCv}_{\mathrm{O}_{2}}$ decreases $(2,14,28)$. In contrast, in humans, minimal changes in $\mathrm{MEO}_{2}$ occur at mild-tomoderate levels of exercise, although an increase in $\mathrm{MEO}_{2}$ and a decrease in coronary venous $\mathrm{O}_{2}$ content have been reported in humans during heavy exercise ( $>85 \%$ of maximum heart rate) (26). Similar to humans, $\mathrm{MEO}_{2}$ and $\mathrm{PCv}_{\mathrm{O}_{2}}$ did not change significantly in swine during treadmill exercise in the present study. Interestingly, Hall et al. (21) reported that interstitial levels of adenosineincreased during $\beta$-adrenergic stimulation with dobutamine in anesthetized swine in the presence of maintained $\mathrm{PCv}_{\mathrm{O}_{2}}$ and interstitial lactate levels, suggesting that adenosine could have contributed to the maintained $\mathrm{PCv}_{\mathrm{O}_{2}}$ during exercise in the present study. However, the results of the present study do not support such a role for adenosine, inasmuch as 8-PT resulted in similar decreases in $\mathrm{PCV}_{\mathrm{O}_{2}}$ at rest and during exercise.

In the present study, adenosine receptor blockade increased coronary as well as systemic vascular resistance at rest and during exercise. Because we did not measure regional blood flows, we cannot determine which vascular beds responded with an increased vascular resistance. However, during exercise a major part of cardiac output is directed toward the active skeletal muscle groups (26). Adenosine has been invoked in the regulation of skeletal muscle vascular tone during exercise. Thus the exercise-induced skeletal muscle hyperemia was blunted by increased adenosine catabolism with adenosine deaminase (35), whereas a decrease in adenosine uptake produced by dipyridamole increased skeletal muscle blood flow during exercise (25). The results from the present study are consistent with a vasodilator influence exerted by adenosine on skeletal muscle resistance vessels during treadmill exercise.

Adenosine receptor blockade had no effect on pulmonary vascular resistance, which would appear to indicate that endogenous adenosine did not contribute to regulation of pulmonary vascular resistance at rest or during exercise. However, $A_{1}$ and $A_{2}$ receptors, both of which are present in the pulmonary bed, mediate pulmonary smooth muscle contraction and relaxation, respectively (3). Because 8-PT is a nonselective $A_{1} / A_{2^{-}}$ receptor antagonist, we cannot exclude the possibility that endogenous adenosine may contribute to regulation of pulmonary resistance vessel tone but that lack of effect of 8-PT on the pulmonary bed could be due to its opposing vasomotor actions via simultaneous $A_{1}$ and $A_{2}$ blockade. Future studies using selective $A_{1^{-}}$and $A_{2}-$ receptor antagonists are required to determine the role of $A_{1}$ - and $A_{2}$-receptor subtypes.

In conclusion, $\mathrm{MEO}_{2}$ and $\mathrm{PCv}_{\mathrm{O}_{2}}$ were not altered from resting levels in swine exercising on a treadmill at levels up to $80-90 \%$ of maximum heart rate, indicating that the exercise-induced increases in $\mathrm{MVO}_{2}$ were matched by equivalent increases in $\mathrm{MDO}_{2}$. Adenosine receptor blockade resulted in an increased $\mathrm{MEO}_{2}$ and a decreased $\mathrm{PCV}_{\mathrm{O}_{2}}$ under resting conditions and during exercise, indicating that endogenously released adenosine exerted a vạsodilator influence that contributed to maintaining $\mathrm{MDO}_{2}$ commensurate with $\mathrm{O}_{2}$ demands. However, adenosine was not mandatory for the exerciseinduced coronary vasodilation in swine.

The authors gratefully acknowledge the technical assistance of Rob H. van Bremen.

The research of $D$. J. Duncker has been made possible by a Research Fellowship of the Royal Netherlands Academy of Arts and Sciences.

Address for reprint requests: D. J . Duncker, Experimental Cardiology, Thoraxcenter, Erasmus University Rotterdam, PO Box 1738, 3000 DR Rotterdam, The Netherlands.

Received 22 April 1998; accepted in final form 21 J uly 1998.

\section{REFERENCES}

1. Bacchus, A. N., S. W. Ely, R. M. Knabb, R. Rubio, and R. M. Berne. Adenosine and coronary blood flow in conscious dogs during normal physiological stimuli. Am. J . Physiol. 243 (Heart Circ. Physiol. 12): H628-H633, 1982.

2. Bache, R. J ., S. Z. Dai, J . S. Schwartz, and D. C. Homans. Role of adenosine in coronary vasodilation during exercise. Circ. Res. 62: 846-853, 1988.

3. Barnes, P. J ., and S. F. Liu. Regulation of pulmonary vascular tone. Pharmacol. Rev. 47: 87-131, 1995.

4. Berne, R. M., and R. Rubio. Regulation of coronary blood flow. Adv. Cardiol. 12: 303-317, 1974.

4a.Breisch, E. A., F. C. White, L. E. Nimmo, M. D. McKirnan, and C. M. Bloor. Exercise-induced cardiac hypertrophy: a correlation of blood flow and microvasculature. J . Appl. Physiol. 60: 1259-1267, 1979.

5. Canty, J . M., J r., and T. P. Smith. Adenosinerecruitable flow reserve is absent during myocardial ischemia in unanesthetized dogs studied in the basal state. Circ. Res. 76: 1079- 1087, 1995.

6. Dewitt, D. F., R. D. Wangler, C. I. Thompson, and H. V. Sparks, J r. Phasic release of adenosine during steady state metabolic stimulation in the isolated guinea pig heart. Circ. Res. 53: 636-643, 1983. 
7. Duncker, D. J ., D. B. Haitsma, I. E. J . Van Der Geest, R. Stubenitsky, J. R. van Meegen, A. J. Man in 't Veld, and P. D. Verdouw. Systemic, pulmonary and coronary haemodynamic actions of the novel dopamine receptor agonist Z1046 in awake pigs at rest and during treadmill exercise. Br. J . Pharmacol. 120: 1101-1113, 1997.

8. Duncker, D. J ., C. Klassen, S. K. Herrlinger, T. J . Pavek, and R. J . Bache. Effects of temperature on myocardial infarction in swine. Am. J. Physiol. 270 (Heart Circ. Physiol. 39): H1189-H1199, 1996.

9. Duncker, D. J ., R. Stubenitsky, and P. D. Verdouw. Autonomic control of vasomotion in the porcine coronary circulation during treadmill exercise: evidence for feed-forward $\beta$-adrenergic control. Circ. Res. 82: 1312-1322, 1998.

10. Duncker, D. J ., N. S. Van Zon, Y. I shibashi, and R. J . Bache. Role of $\mathrm{K}_{A T P}^{+}$channels and adenosine in regulation of coronary blood flow during exercise with normal and restricted coronary blood flow. J. Clin. Invest. 97: 996-1009, 1996.

11. Edlund, A., T. Conradsson, and A. Sollevi. A role for adenosine in coronary vasoregulation in man. Effects of theophylline and enprofylline. Clin. Physiol. 15: 623-636, 1995.

12. Edlund, A., and A. Sollevi. Theophylline increases coronary vascular tonein humans: evidence for a role of endogenous adenosine in flow regulation. Acta Physiol. Scand. 155: 303- 311, 1995.

13. Edlund, A., A. Sollevi, and A. Wennmalm. The role of adenosine and prostacyclin in coronary flow regulation in healthy man. Acta Physiol. Scand. 135: 39- 46, 1989.

14. Ely, S. W., R. M. Knabb, A. N. Bacchus, R. Rubio, and R. M. Berne. Measurements of coronary plasma and pericardial infusate adenosine concentrations during exercise in conscious dogs: relationship to myocardial oxygen consumption and coronary blood flow. J . Mol. Cell. Cardiol. 15: 173- 183, 1983.

15. Fan, D., L. K. Soei, R. Stubenitsky, E. Boersma, D. J . Duncker, P. D. Verdouw, and R. Krams. Contribution of asynchrony and nonuniformity to mechanical interaction in normal and stunned myocardium. Am. J . Physiol. 273 (Heart Circ. Physiol. 42): H2146-H2154, 1997.

16. Feigl, E. O. Coronary physiology. Physiol. Rev. 63: 1-205, 1983.

17. Gewirtz, H., R. A. Olsson, D. L. Brautigan, P. R. Brown, and A. S. Most. Adenosine's role in regulating basal coronary arteriolar tone. Am. J . Physiol. 250 (Heart Circ. Physiol. 19): H1030H1036, 1986.

18. Gewirtz, H., R. A. Olsson, and A. S. Most. Role of adenosine in mediating myocardial blood flow response to isoproterenol: observations in closed chest, sedated, domestic swine. Cardiovasc. Res. 20: 504-511, 1986

19. Giles, R. W., and D. E. L. Wilcken. Reactive hyperaemia in the dog heart: interrelationships between adenosine, ATP, and aminophylline and the effect of indomethacin. Cardiovasc. Res. 11: 113-121, 1977.

20. Griffith, S. G., P. Meghji, C. J . Moody, and G. Burnstock. 8-Phenyltheophylline: a potent $\mathrm{P}_{1}$-purinoceptor antagonist. Eur.J . Pharmacol. 75: 61-64, 1981.

21. Hall, J. L., D. G. L. Van Wylen, R. D. Pizzuro, C. D. Hamilton, C. M. Reiling, and W. C. Stanley. Myocardial interstitial purine metabolites and lactate with increased work in swine. Cardiovasc. Res. 30: 351- 356, 1995.

22. Hanley, F. L., M. T. Grattan, M. B. Stevens, and J . I. E. Hoffman. Role of adenosine in coronary autoregulation. Am. J . Physiol. 250 (Heart Circ. Physiol. 19): H558-H566, 1986.

23. Ishida, T., R. M. Lewis, C. J . Hartley, M. L. Entman, and J. B. Field. Comparison of hepatic extraction of insulin and glucagon in conscious and anesthetized dogs. Endocrinology 112: 1098-1109, 1983.

24. Kroll, K., and E. O. Feigl. Adenosine is unimportant in controlling coronary blood flow in unstressed dog hearts. Am. J . Physiol. 249 (Heart Circ. Physiol. 18): H 1176- H 1187, 1985.

25. Laughlin, M. H., R. E. Klabunde, M. D. Delp, and R. B. Armstrong. Effects of dipyridamole on muscle blood flow in exercising miniature swine. Am. J . Physiol. 257 (Heart Circ. Physiol. 26): H1507-H1515, 1989.

26. Laughlin, M. H., R. Korthuis, D. J . Duncker, and R. J . Bache. Regulation of blood flow to cardiac and skeletal muscle during exercise. In: Handbook of Physiology. Exercise: Regulation and Integration of Multiple Systems. Bethesda, MD: Am. Physiol. Soc., 1996, sect. 12, chapt. 16, p. 705- 769.

27. Martin, S. E., W. C. Tidmore, and R. E. Patterson. Adenosine receptor blockade with 8-sulfophenyltheophylline aggravates coronary constriction. Am. J . Physiol. 260 (Heart Circ. Physiol. 29): H1753-H1759, 1991.

28. McKenzie, J . E., R. P. Steffen, and F. J . Haddy. Relationship between adenosine and coronary resistance in conscious exercising dogs. Am. J . Physiol. 242 (Heart Circ. Physiol. 11): H24-H29, 1982.

29. Merrill, G. F., F. J . Haddy, and J . M. Dabney. Adenosine, theophylline, and perfusate $\mathrm{pH}$ in the isolated, perfused guinea pig heart. Circ. Res. 42: 225-229, 1978.

30. Olsson, R. A., R. Bunger, and J . A. E. Spaan. Coronary circulation. In: The Heart and Cardiovascular System, edited by H. A. Fozzard, E. Haber, R. B. J ennings, A. M. Katz, and H. E. Morgan. New York: Raven, 1992, p. 1393-1426.

31. Randall, M. D. The involvement of ATP-sensitive potassium channels and adenosine in the regulation of coronary flow in the isolated perfused rat heart. Br. J . Pharmacol. 116: 3068-3074, 1995.

32. Rossen, J . D., H. Oskarsson, R. L. Minor, C. L. Talman, and M. D. Winniford. Effect of adenosine antagonism on metabolically mediated coronary vasodilation in humans. J. Am. Coll. Cardiol. 23: 1421-1426, 1994.

33. Saito, D., C. R. Steinhart, D. G. Nixon, and R. A. Olsson. Intracoronary adenosine deaminase reduces canine myocardial reactive hyperemia. Circ. Res. 49: 1262-1267, 1981.

34. Schutz, W., M. Zipfer, and G. Raberger. Effect of aminophylline on coronary reactive hyperaemia following brief and long occlusion periods. Cardiovasc. Res. 11: 507-511, 1977.

35. Schwartz, L. M., and J . E. McKenzie. Adenosine and active hyperemia in soleus and gracilis muscle of cats. Am. J . Physiol. 259 (Heart Circ. Physiol. 28): H1295-H1304, 1990.

36. Sparks, H. V., J r., and H. Bardenheuer. Regulation of adenosine formation by the heart. Circ. Res. 58: 193-201, 1986.

37. Stubenitsky, R., R. W. P. van der Weerd, D. B. Haitsma, P. D. Verdouw, and D. J . Duncker. Cardiovascular effects of the novel $\mathrm{Ca}^{2+}$-sensitizer EMD 57033 in chronically instrumented pigs at rest and during exercise. Br. J . Pharmacol. 122: 12571270, 1997.

38. Stubenitsky, R., P. D. Verdouw, and D. J . Duncker. Autonomic control of cardiovascular performance and whole body $\mathrm{O}_{2}$ delivery and utilization in swine during treadmill exercise. Cardiovasc. Res. 39: 459-474, 1998.

39. Watkinson, W. P., D. H. Foley, R. Rubio, and R. M. Berne. Myocardial adenosine formation with increased cardiac performance in the dog. Am. J . Physiol. 236 (Heart Circ. Physiol. 5): H13-H21, 1979. 